\title{
AGRICULTURAL SUSTAINABILITY AND SOCIAL RESPONSIBILITY
}

Marijana Dukić Mijatović ${ }^{1}$ Ozren Uzelac ${ }^{2}$, Aleksandra Stoiljković3

*Corresponding author E-mail: ozren.uzelac@ef.uns.ac.rs

\begin{abstract}
A R T I C LE I N F O
A B S T R A C T

Review Article

Exchange of the drought and precipitations due to climate

Received: 17 November 2021

Accepted: 08 December 2021

doi:10.5937/ekoPolj2104109D

UDC [502.131.1:631 ]:005.35 changes is preventing higher agrarian output. Although modern technology and methods of farm production may be the answer to this question, these raise public concerns about employment and environment quality. Because of demographic and technological lagging, some countries face other problems of achieving agronomic sustainability.

Keywords:

agriculture, sustainability, social responsibility, climate changes In this paper, the importance of sustainable agriculture development, legal bases and some aspects of agricultural social responsibility are explored. Comparative and logical deduction methods of reviewing the selected international and national documents and literature were employed. Authors conclude there are adequate legal frameworks

JEL: K000, Q010, M140 for agricultural social responsibility and the discussion if agriculture's moral priorities affect its economic performance will never end.
\end{abstract}

(C) 2021 EA. All rights reserved.

\section{Introduction}

Traditional methods of achieving a higher agricultural yield are being replaced by introducing innovations like "precision farming", automation and digitization. As the application of more efficient pesticides, specific methods of farming and other advanced measures spread so is the importance of public concerns about the impact of agricultural modernization on social and environmental issues.

However, the use of new technologies may mitigate environmental risks and concerns, but not social issues as we will see in this paper. For example, the farm machinery can

1 Marijana Dukić Mijatović, Associate Professor, Faculty of Technical Sciences, University of Novi Sad, Trg Dositeja Obradovića 6, 21000 Novi Sad, Phone: +381 21450 810, E-mail: marijana.mijatovic@uns.ac.rs, ORCID ID (https://orcid.org/0000-0001-9535-2962)

2 Ozren Uzelac, Assistant Professor, Faculty of Economics in Subotica, University of Novi Sad, Segedinski put 9-11, 24000 Subotica, Phone: +381 24628 059, E-mail: ozren.uzelac@ ef.uns.ac.rs, ORCID ID (https://orcid.org/0000-0001-6991-1644)

3 Aleksandra Stoiljković, Teaching Assistant, Faculty of Economics in Subotica, University of Novi Sad, Segedinski put 9-11, 24000 Subotica, Phone: +381 24628 062, E-mail: aleksandra.stoiljkovic@ef.uns.ac.rs, ORCID ID (https://orcid.org/0000-0002-4324-4537) 
be given targeted pesticide application and irrigation orders, while providers of data analytics can collect environmental data and comprehensive plant pathogen information that can be called up at any time to improve the crop management (Bayer, 2016, 77). On the other hand, social issues may not be as quantifiable as environmental impact.

With stable World population growth, there has been a need to accelerate nourishment production to ensure sustainable development. United Nations (UN) estimate that the current world community is expected to reach 9.7 billion in 2050 (United Nations, 2015a), whereas the UN's Food and Agriculture Organization (FAO) suggested that the food production would have to double by 2050 to meet projected demand (Food and Agriculture Organization of the United Nations, 2009, 13). However, the capacity of present resources and technologies that should meet the demands of a growing population for food and other agricultural products remains uncertain (Popović, Kovljenić, 2017, 1500; Stevanović, Đurđević, 2018, 82). Exchange of the drought and precipitations due to climate changes is preventing higher agricultural output. However, together with the population rising and greater consumption, the world may need even more ideas and innovative methods that will create major farming revolution. The common answer lies in sustainable development partly by the agricultural social responsibility (Hereinafter: ASR).

In this paper, the authors explore importance of sustainable agriculture development, legal bases and some aspects of agricultural social responsibility.

\section{Sustainable agricultural development}

Norwegian Prime Minister Mrs Gro Harlem Brundtland developed at the end of the 80 s generally accepted definition of the sustainable development. It takes into account progress that satisfies current needs and ensures the future generations capability to meet their essentials (Brundtland, 1987, 27). One of the proclaimed goals in the UN Resolution 70/1. Transforming our world: the 2030 Agenda for Sustainable Development was to eradicate famine, create a food security system that would enhance the diet and promote viable agriculture (United Nations, 2015b, Goal 2). The priorities in the said UN Resolution on sustainable agriculture show its multifunctional dimension as one of the important tools in sustainable development management. It is reflected in social, economic and environmental roles. As claimed by Bitsch, most authors use various approaches to the models' concepts of sustainability and social responsibility on equal footing (Bitsch, 2011, 1). Also, some authors claim that sustainability serves as a prospective explanation of the need for CSR (Porter, Kramer, 2006). The moral acceptability of conduct or a decision depends on the way of observing the outcome. Put differently, is Monsanto (agricultural company faced with controversy in the USA over genetically modified wheat and herbicide products - added by the authors) behaving ethically or practicing "sustainable agriculture" by producing genetically modified seeds or is eradicating poverty in developing nations their corporate social responsibility (Hereinafter: CSR) strategy? (Smith, 2011, 71). 
It is customary to claim that social sustainability impacts society through societal, social, labor and general human rights (Bitsch, 2011). Hohnen and Hediger point out that building social capital is as important as economic and natural resources (or raw materials) for CSR. They claim where social capital refers to the firm's relationship with society, how it is perceived and regarded (Hohnen, 2007, 77; Hediger, 2008, 10).

In line with the Brundtland definition, transposition of the principle of sustainability into a legislative form is part of the countries' constitutions. Those constitutions are phrased differently but reflect the essential meaning of sustainability. For example, the Constitution of the Federal Republic of Germany provides the state protects the basics of life and the animals as the responsibility for the generations to come (Basic Law for the Federal Republic of Germany). Serbian Constitution stipulates the Republic of Serbia shall ensure a uniform and sustainable regional development in accordance with the law. It shall regulate and provide systems for the protection and enhancement of the environment, flora and fauna, whereas municipalities are competent for the improvement and use of agricultural land (Constitution of the Republic of Serbia). Rules of a sustainable conduct from the Constitution are transposed in detail by law. For example, there are general and particular principles of fiscal policy in the Serbian Budget System Act, whereas only a few of them are dedicated to sustainability. The standard of fairness requires the fiscal policy management must take into account its impact on the welfare of all generations. However, the management of the national assets and liabilities and resources must not burden upcoming generations (Budget System Act).

On the European Union level, the European Commission has also stressed the importance of corporate social responsibility for sustainable development in A Renewed EU Strategy 2011-14 for CSR (European Commission, 2011). European Commission claimed that "Through CSR, enterprises can significantly contribute to the European Union's treaty objectives of sustainable development and a highly competitive social market economy (European Commission, 2011, 3)."

The European Commission survey from December 2017, showed 55\% of the respondents were most likely to say one of the primary farmers' responsibilities in society was providing healthy food of high quality. Additional $25 \%$ say it is about protecting the environment and tackling climate change (European Commission, 2018, 6). How important is to promote adequate policies and work on enforcement of their goals confirms half of all respondents in 24 EU member countries. They agree the Common Agricultural Policy is fulfilling its role in preserving the environment and tackling climate change (European Commission, 2018, 12).

The same challenges bother Serbian agricultural production as well, where the modernization of the agricultural machinery remains a particular issue that need to be addressed. The average area of the agricultural land cultivated by a two-axle tractor was 8.5 hectares according to the Strategy of Agriculture and Rural Development of the Republic of Serbia for the period 2014-2024 (Hereinafter: The Strategy) (Strategy of Agriculture and Rural Development of the Republic of Serbia for the period 2014- 
2024, 2.2.4). Authors of this document claim that the Serbian farmers use agricultural machines with narrower operating span, incurring higher fuel consumption and harvest losses, which additionally increase production costs (Strategy of Agriculture and Rural Development of the Republic of Serbia for the period 2014-2024, 2.2.4). Likewise, aged machinery and scarce investment hinder the increase of the productivity and profitability of the Serbian agricultural sector. Also, intensive manufacturing and longer food supply chains may be associated with higher greenhouse gas emissions from production machinery. This explains why Serbian agriculture urgently needs modernization of the machines and equipment. Size of agricultural holdings augmentation, health security standards, and animal welfare and climate changes are some of the reasons.

As seen from the above, achievement of the sustainable development remains a complex issue for many reasons. Despite EU agriculture having made real progress on the climate and nature front since 1990, food production continues to put a strain on our environment (European Commission, 2019, 19). Still, a way to improve the environmental sustainability of the global food system as claimed by the UN Food and Agriculture Organization is the loss and waste reduction (FAO, 2019). However, based on a few studies, this organization has concluded that efforts based on business considerations alone are unlikely to resolve said production issues (FAO, 2019). That necessitates a change of the economic and legal landscape under which decisions about food loss and waste are made. To this end, the European Commission adopted a Delegated Act on 3 May 2019, laying down a common food waste measurement methodology. Such methodology serves for quantifying those indicators at each stage of the supply chain (Commission Delegated Decision (EU) 2019).

Regarding what principles sustainable agriculture should follow, Ganzi has claimed it must produce high yield and nutrition quality crops keeping resources use at the lowest level; minimize any adverse effects on the environment and make every effort towards positive sustainability contributions; utilize the renewable assets more often than non-renewable resources; and should give the local communities ability to keep and progress in their wellbeing (Ganzi, 2006, 4). Notwithstanding Ganzi's alimentary, environmental and social principles, Tarnapol Whitacre highlights an economic aspect of agricultural sustainability reflected in the profitability and viability of the farming business. As they claim, once achieved, it represents a process that changes farming systems permanently in accordance with the socially determined consistency goals. More concisely than the above Ganzi's principles, they define agricultural sustainability by four generally agreed upon goals: satisfy various needs, improve ecological aspects, achieve economic stability of agriculture and take forward the farm and society life quality (Tarnapol Whitacare, 2010, 1).

\section{Agricultural social responsibility}

Corporate social responsibility is understood to be the way companies combine social, environmental and economic concerns into their values, culture, decision making, strategy and operations. By applying such values and practices they contribute to the well-being of an individual and society (Hohnen, 2007, 5; International Organization 
for Standardization, 2010). Hohnen advocates for a pragmatic "license-to-operate" approach. This approach offers a concrete way to identify social issues vital to the company's stakeholders and fosters dialogue with local government, community and non-governmental organizations. In the view of Caroll, CSR involves the conduct of a business so that it is economically profitable, law-abiding, ethical and socially supportive (Caroll, 1999, 286). Caroll explains the expression ,socially supportive” as a voluntary or philanthropic part of the social responsibility. However, we believe such concepts are hardly acceptable in the context of agricultural production.

As something sensitive to regulate by imperative legislation, guidelines of the various international organizations are vital for adopting good governance and production practice in agriculture. Some of these, recommended by the BNP Paribas, are FAO Voluntary Guidelines on the responsible governance of tenure of land, fisheries and forests in the context of national food security 2012; OECD FAO Guidance for Responsible Agricultural Supply Chains 2016 (to help enterprises observe existing standards for responsible business conduct along agricultural supply chains); World Bank Environmental, Health, and Safety General Guidelines 2007 (for Agribusiness and Food production sectors); The CEO Water Mandate's Corporate Water Disclosure Guidelines Toward a Common Approach to Reporting Water Issues, September 2014 and other guidelines and certifications (BNP Paribas).

In the absence of imperative statutory provisions that would direct sustainability initiatives in a desirable course, morality and conscientiousness in agricultural production are of utmost importance. And corporate social responsibility represents only one component of sustainable development. A typical example is producers and retailers who increasingly engage in CSR initiatives to show their commitment to sustainability issues like animal welfare and environment (De Olde, Valentinov, 2019, 415). However, large and small individual farms can contribute both positively and negatively to sustainability in various degrees. Tempting question if it is worth pursuing sustainability objectives or maintaining the imperative balance between various aspects of sustainability (e.g. economic viability, ecosystem functioning, social responsibility, and food characteristics) is basically a social choice (Tarnapol Whitacre, 2010, 271). Continuity of work processes in farming together with the everyday family life, made Bitsch express concern on the social aspects of farmers' production and responsibility (Bitsch, 2011,2). Whatever the approach to steering the ASR, Tarnapol Whitacre claims maintaining farm profitability is a critical link to ensuring farm dollars circulate in the local economy (Tarnapol Whitacre, 2010, 73).

Higher food production at low prices for consumers with a fair income for farmers was an ethical conception of justice and fairness for many decades (De Olde, Valentinov, 2019, 422-423). Today, agricultural social responsibility dictates an essentially different approach from this principle. However, mechanization, use of milking machines, digital farming, etc. reduce the necessity of using too much manual work. For example, in the area of animal production, in longer period, numbers of animals remained rather constant or increased, while the number of full-time farm workers hardly increased resulting in more animals per labor unit (De Olde, Valentinov, 2019, 422-423). 
With farming systems' industrialization there have been growing concerns over negative socio-economic impacts on the local communities. As found in the literature, the majority of empirical studies (57\%) confirmed the negative effects of industrialized agriculture on the community well-being when it comes to quantity and quality of the farm jobs, the extent to which farms purchase inputs and sell outputs locally, the local poverty rate and the level of income inequality (Tarnapol Whitacre, 2010, 73).

What can be claimed for some agricultural regions as regards to jobs density, does not apply for the agriculture in general. Agriculture still provides the highest proportion of jobs. It plays an important role in less developed countries, where farming jobs make a considerable share of the total workforce compared to less than 5\% in France, Italy and Spain (Rivoal, 2012, 198).

In the area of metrics, labor issues are more difficult to measure than environmental impacts. Labor concerns include wages and benefits, health and safety, stable employment, compliance with laws and international conventions and employee participation in improving workplace conditions (Bitsch, 2011, 3; Hohnen, 2007, 24). Contrary to these views, a survey conducted in Ukraine in spring 2016 has shown the most of the agricultural managers does not consider staff development and improving working conditions as an important part of CSR (Levkivska, Levkovych, 2017, 106).

Production of more and more food is as important as achieving and maintaining its sufficiency and safety. Therefore, there is a general agreement that to pursue agricultural sustainability and responsibility in farming systems, farmers need to apply complex cropping rotations, integrated crop and livestock production and use environmentally friendly means to control vermin and crop disease-prone nature (monitoring their recognizing their interconnectedness and interactions with the environment) (Tarnapol Whitacre, 2010, 2; FAO, 2019). To this end, in Serbia farms with fragmented holdings and applied organization of production, have high production costs and inefficient use of resources (Popović, Kovljenić, 2017, 1501).

How important is the creation of jobs and economic growth in rural areas of the less developed regions shown in the EU Special Eurobarometer survey from December 2017. In 28 EU Member States, about $25 \%$ of the farmers believe the environment protection and addressing climate changes are more important than agricultural growth and creation of jobs. There are 27\% in Hungary, 28\% in Romania, 30\% in Croatia and $34 \%$ farmers in Bulgaria of the opposite belief (European Commission, 2018). This could mean farmers in the latter countries will be less likely environmentally mindful. They will also be careless about creating conditions for stronger economic development and addressing labor concerns. For example, although large agricultural companies are major investors and employers in rural areas of Ukraine, they are sometimes blamed for exploiting resources and are careless about the environmental consequences (Levkivska, Levkovych, 2017, 98). As outlined in the Serbian theory, most advanced countries should recognize preferential treatment to undeveloped countries as a support in their efforts to access foreign markets of agricultural products (Rabrenović, Popov, 
Stamenović, 2020, 75). If such a step is undertaken, preferential treatment could be one of the fundamental aspects for boosting the ASR.

One may ask himself is there really an agricultural environmental responsibility? There are at least two reasons for such a question. Firstly, sometimes reckless companies and people intend to conceal the harmful consequences of their ill-managed practice and mitigate its relevance for the specific event. Consequently, if they succeed to show the soundness of their practice in the specific event, they can exonerate themselves from civil liability for environmental damage. Secondly, carbon, land and water footprints are dependent on the food product, production method and the stage where loss or waste occurs. The land and water footprints of food are concentrated at the primary production stage. Despite significant amounts of water may be used during processing, greenhouse gases' emissions may occur and accumulate along the entire supply chain (FAO, 2019, 92). This "dilemma" shows how sustainability and responsibility of the agricultural business can be defended somewhat immorally.

Beside economic and social aspects, socially responsible agriculture is distinguished by the efficiency of the environmentally friendly production methods and minimization of their business's negative consequences. Otherwise, it risks being blamed by NGOs or mass media if they do not behave in an adequate way, which can negatively affect their reputation and financial performance (Hediger, 2008, 9; Hohnen, 2007, 2).

The moral complexity of corporate social responsibility in agriculture is the same as in other parts of the economy. How to converge economic, social and environmental goals and keep the image of a responsible business towards the public is a moral question. The answer can show the boundary between socially acceptable and irresponsible organization. Moral complexity means that quite many societal expectations directed toward agriculture are marked by a high degree of moral legitimacy. However, they are far from converging on any consensus (De Olde, Valentinov, 2019, 420). As CSR is strongly imbued with a moral imperative, it is the nature of moral obligations to be absolute mandates, while most corporate choices involve balancing competing values, interests, and costs (Porter, Kramer, 2006). As something beyond what is required by the law, ethical responsibility represents the behaviors and ethical norms that society expects business to follow (Caroll, 1999, 283). Moral motivation, manager's personal ethics and values (Levkivska, Levkovych, 2017, 100; De Olde, Valentinov, 2019, 425) are embraced by the concern for the welfare of all generations and belief that it is the "right thing to do" and concern for the welfare of present and future generations (Hohnen, 2007, 13). These are some of the CSR's internal drivers decisively influencing the balance between company's business goals and social and environmental conduct. One may argue CSR could be burdensome for improving business's financial performance if often or to a significant extent pays attention to social and environmental issues. However, some authors claim both models can produce the same results if managed as a system. That implies the inclusion of wealth production and distribution, ethical systems and sustainable management practices (Smith, 2011, 30; Hohnen, 2007, 11; Hediger, 2008, 4). 
In economic theory, there is a general agreement about corporate social responsibility correlation with profitability, but disagreement over its effect. One group of authors concluded that corporate social performance and research \& development (Hereinafter: R\&D) aspects are highly correlated. Furthermore, when R\&D intensity is included in the equation, corporate social performance is shown to have a neutral effect on profitability (McWilliams, Siegel, 2000). The other group found that the corporate virtue in the form of social and, to a lesser extent, environmental responsibility is rewarding in more ways than one (Orlitzky, Schmidt, Rynes, 2003, 427).

\section{Conclusions}

The generally accepted principle of sustainable development of human society has been a matter much discussed in theory and recognized by international institutions and various initiatives. They all agree a sustainable development is a starting point for a better, peaceful and justly developed world. This concerns both present and future generations.

International and national levels of legal regulation provide adequate bases for agricultural social responsibility.

However, there are many obstacles to the achievement of sustainable development. These refer to the social and environment issues affected by the economic expectations in terms of productivity and profitability of the agribusiness. Specific methods of agricultural production and food distribution are additional aspects in that field.

Morality is another dimension of the CSR relevant for differentiation of the agribusiness's acceptability by the society from irresponsible conduct forms. Although CSR may prove to be burdensome for improving business's financial performance, there is disagreement over its effect on profitability. Notwithstanding the importance of the sustainability and social responsibility of the agribusiness, discussion if the moral priorities affect agriculture's economic performance and core activity will never end.

\section{Conflict of interests}

The authors declare no conflict of interest.

\section{References}

1. Basic Law for the Federal Republic of Germany in the revised version published in the Federal Law Gazette Part III, classification number 100-1, as last amended by Article 1 of the Act of 15 November 2019 (Federal Law Gazette I p. 1546) [in German: Grundgesetz für die Bundesrepublik Deutschland in der im Bundesgesetzblatt Teil III, Gliederungsnummer 100-1, veröffentlichten bereinigten Fassung, das zuletzt durch Artikel 1 des Gesetzes vom 15. November 2019 (BGBl. I S. 1546) geändert worden ist]. 
2. Bayer CropScience (30 November 2016). The networked farm. Bayer Research, 76-81.

3. BNP Paribas. (n/a). Corporate Social Responsibility: Agriculture Sector Policy. Retrieved from: https://group.bnpparibas/uploads/file/position_paper_soft_ commodities_format_corporate_final.pdf (15.1.2021).

4. Bitsch, V. (2011). Sustainability Agriculture, Social Responsibility and Dairy Farming. Michigan Dairy Review 16(1), 1-4. Retrieved from: https:/www.canr. msu.edu/uploads/234/76566/Sustainability_Agriculture.pdf(15.1.2021).

5. Brundtland, G. H. (1987). Report of the World Commission on Environment and Development: Our Common Future. World Commission on Environment and Development, United Nations, New York. Retrieved from: http://www.undocuments.net/our-common-future.pdf (15.1.2021).

6. Budget System Act, Official Gazzette of the Republic of Serbia, 54/2019, 73/2010, 101/2010, 101/2011, 93/2012, 62/2013, 63/2013 - correction, 108/2013, 142/2014, 68/2015 - other law, 103/2015, 99/2016, 113/2017, 95/2018, 31/2019, 72/2019 [in Serbian: Zakon o budžetskom sistemu, Službeni glasnik Republike Srbije, 54/2019, 73/2010, 101/2010, 101/2011, 93/2012, 62/2013, 63/2013 - ispravka, 108/2013, 142/2014, 68/2015 - drugi zakon, 103/2015, 99/2016, 113/2017, 95/2018, 31/2019, 72/2019].

7. Carroll, A. B. (1999). Corporate social responsibility: Evolution of a definitional construct. Business \& society, 38(3), 268-295. (https://doi.org/10.1177/00076503 9903800303).

8. Commission Delegated Decision (EU) 2019/1597 of 3 May 2019 supplementing Directive 2008/98/EC of the European Parliament and of the Council as regards a common methodology and minimum quality requirements for the uniform measurement of levels of food waste, Official Journal of the European Union, L 248, 27.9.2019, 77-85.

9. Constitution of the Republic of Serbia, Official Gazzette, No. 98, 10 November 2006 [in Serbian: Ustav Republike Srbije, Službeni glasnik RS, 98 od 10. novembra 2006].

10. De Olde, E. M., \& Valentinov, V. (2019). The moral complexity of agriculture: A challenge for corporate social responsibility. Journal of Agricultural and Environmental Ethics, 32(3), 413-430. https://doi.org/10.1007/s10806-019-097823 (15.1.2021).

11. European Commission (2019). Reflection paper: Towards a sustainable Europe by 2030, COM (2019)22 of 30 January 2019, European Commission, Brussels. Retrieved from: https://ec.europa.eu/transparency/regdoc/rep/1/2019/EN/COM2019-22-F1-EN-MAIN-PART-1.PDF, (15.1.2021).

12. European Commission (2018). Europeans, Agriculture and the CAP, Special Eurobarometer 473, 22.2.2018. Retrieved from: https://data.europa.eu/euodp/en/ data/dataset/S2161_88_4_473_ENG. (15.1.2021). 
13. European Commission (2011). Communication from the Commission to the European Parliament, the Council, the European Economic and Social Committee and the Committee of the regions - A renewed EU strategy 201114 for Corporate Social Responsibility, $\operatorname{COM}(2011) 681$ final, Brussels, 25.10.2011. Retrieved from: https://eur-lex.europa.eu/legal-content/EN/TXT/ PDF/?uri=CELEX:52011DC0681 (15.1.2021).

14. FAO (2019). The state of food and agriculture - Moving forward on food loss and waste reduction, Food and Agriculture Organization of the United Nations, Rome. Retrieved from: http://www.fao.org/3/ca6030en/ca6030en.pdf, (15.1.2021).

15. Food and Agriculture Organization of the United Nations (1-5 June 2009). Report of the Governing Body of the International Treaty on Plant Genetic Resources for Food and Agriculture, Third Session of the Governing Body of the International Treaty on Plant Genetic Resources for Food and Agriculture, Tunis. Retrieved from: http://www.fao.org/3/a-be112e.pdf (15.1.2021).

16. Ganzi, J. (2006). Sustainable Agriculture, Corporate Social Responsibility (CSR) \& The Private Sector of the Financial Services Industry, Public Private Partnerships for Sustainable Development in the Americas, Organization of American States, 22nd November, 2006, 1-12. Retrieved from: http://www.oas.org/dsd/EnvironmentLaw/trade/Documents/paper\%2011-22\%20final\%20paper.pdf, (15.1.2021).

17. Hediger, W. (2008). Agriculture's Multifunctionality, Sustainability, and Social Responsibility, Paper prepared for presentation at the 82nd annual conference of the Agricultural Economics Society (AES) at the Royal Agricultural College, 31st March - 2nd April 2008, 1-14. Retrieved from: https://core.ac.uk/download/ pdf/7010962.pdf (15.1.2021).

18. Hohnen, P. (2007). Corporate Social Responsibility: An Implementation Guide for Business, International Institute for Sustainable Development, Winnipeg. Retrieved from: https://www.iisd.org/pdf/2007/csr_guide.pdf(15.1.2021).

19. International Organization for Standardization (2010). ISO 26000:2010(en) Guidance on social responsibility. Geneva: ISO/TMB Working Group on Social Responsibility. Retrieved from: https://www.iso.org/obp/ui/\#iso:std:iso:26000:ed1:v1:en, (15.1.2021).

20. Levkivska, L., \& Levkovych, I. (2017). Social responsibility in Ukrainian agriculture: the regional issue. Eastern Journal of European Studies, 8(1), 97-114. Retrieved from: http://ejes.uaic.ro/articles/EJES2017_0801_LEV.pdf, (15.1.2021).

21. McWilliams, A., \& Siegel, D. (2000). Corporate social responsibility and financial performance: correlation or misspecification?. Strategic management journal, 21(5), 603-609. Retrieved from: https://doi.org/10.1002/(SICI)10970266(200005)21:5<603::AID-SMJ101>3.0.CO;2-3, (15.1.2021).

22. Orlitzky, M., Schmidt, F., \& Rynes, S. (2003). Corporate Social and Financial Performance: A Meta-analysis. Organization Studies, 24(3), 403-441. Retrieved from: https://doi.org/10.1177/0170840603024003910, (15.1.2021). 
23. Popović, R., \& Kovljenić, M. (2017). Efficiency of wheat production in Republic of Serbia. Economics of Agriculture, 64(4), 1499-1511.

24. Porter M. E., \& Kramer M. R. (December 2006). Strategy and Society: The Link between Competitive Advantage and Corporate Social Responsibility. Harvard Business Review, 1-13. Retrieved from: https://hbr.org/2006/12/strategyand-society-the-link-between-competitive-advantage-and-corporate-socialresponsibility, (15.1.2021).

25. Rabrenović, M., Popov, D., \& Stamenović, M. (2020). Stepen ostvarene liberalizacije ekonomije Srbije u procesu pristupanja Svetskoj trgovinskoj organizaciji. Megatrend revija, 17(3), 65-78. [in English: Rabrenović, M., Popov, D., \& Stamenović, M. (2020). Degree of liberalization in Serbian economy as a part of the accession process to the World Trade Organization. Megatrend Review 17(3), 65-78.].

26. Rivoal, C. (2012). Chapter 9. Social responsibility in agriculture, 197-210, in: Francisco Mombiela (publication editor): Mediterra 2012. The Mediterranean Diet for Sustainable Regional Development, / International Centre for Advanced Mediterranean Agronomic Studies (CIHEAM), Presses de Sciences Po, Paris.

27. Smith, R. E. (2011). Defining corporate social responsibility: A systems approach for socially responsible capitalism. Master of Philosophy Theses, University of Pennsylvania, Philadelphia. Retrieved from: https://repository.upenn.edu/cgi/ viewcontent.cgi?article $=1009 \&$ context $=$ od_theses_mp, (15.1.2021).

28. Stevanović, M., \& Đurđević, D. (2018). Dostupnost i pristup slatkoj vodi sa aspekta nacionalne bezbednosti. Megatrend revija, 15(2), 73-94. [in English: Stevanović, M., \& Đurđević, D. (2018). Water safety from the national security aspect. Megatrend Review 15(2), 73-94.].

29. Strategy of Agriculture and Rural Development of the Republic of Serbia for the period 2014-2024, Official Journal of the Republic of Serbia, No. 85/2014 [in Serbian: Strategija poljoprivrede i ruralnog razvoja Republike Srbije za period 2014-2024. godine, Službeni glasnik Republike Srbije, 85/2014].

30. Tarnapol Whitacre, P. (Editor) (2010). Toward Sustainable Agricultural Systems in the 21st Century, Washington D.C.

31. United Nations (2015a). World population projected to reach 9.7 billion by 2050. Retrieved from: http:/www.un.org/en/development/desa/news/population/2015report.html, (15.1.2021).

32. United Nations (2015b). Transforming our world: the 2030 Agenda for Sustainable Development, United Nations General Assembly Resolution A/RES/70/1. New York. Retrieved from: www.un.org/ga/search/view_doc.asp?symbol=A/ $\mathrm{RES} / 70 / 1 \&$ Lang=E, (15.1.2021). 